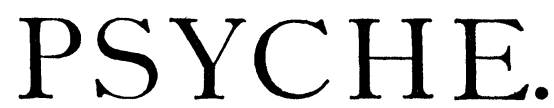

ORGAN OF THE CAMBRIDGE ENTOMOLOGICAL CLUB

EDITED BY GEORGE DIMMOCK AND B. PICKMAN MANN.

Vol. II.] Cambridge, Mass., March-April, 1878. [Nos. 47-48.

\title{
Notes on some Noctuid Larvæ found about Newton, Mass.
}

Apatela radcliffei Harvey. Color black. Three bright yellow lateral bands, the inferior about twice as broad as the two superior ones: also a narrow dorsal band of the same color. Eleventh and twelfth segments deep black above and separated by a yellow line; eleventh a good deal hunched. The whole larva is sparsely covered with very small warts from which project a few short, fine, dirty-white hairs mingled with a few much longer ones. Legs black. Head black below and dull crimson above, with a few projecting hairs. Length $37 \mathrm{~mm}$. Found on wild cherry (Prunus serotina). One, taken before the last moult, was light apple-green with a lozenge-shaped red patch above, and could not be distinguished from the larva of Apatela clarescens. When at rest this larva elevates the fore part of its body, bending back its head, so that it would easily be mistaken for a young larva of Datana, which it almost seems to mimic. It spins a slight cocoon composed of silk interwoven with bits bitten out of the substance on which it spins. Before spinning, the yellow lines turn milky white. The pupa is slender and has a curious olive tint. The moth appears early in June.

Apatela spinigera Guen. Color blackish brown. On each segment are eight warts from which project thick clusters of bristly hairs, three on each side which are single, and two ahove which are double and larger than the rest. On the first and on the last two segments the hairs are dirty blackish, but on the third the four upper tufts are deep crimson at the base and become black at their extremities; a few crimson hairs in 
the corresponding tufts of the second segment. On the remaining segments, excepting the last two, the four upper tufts are of a clearer shade of white. The remaining tufts are dirty blackish. On the eleventh segment the double warts become each two separate ones, placed longitudinally. Legs black. Head black, with a $\bigvee$-shaped lighter mark. A few lighter blotches above, at the bases of the double warts. Length $40 \mathrm{~mm}$. One, found October 5, spun October 9 a loose cocoon of white silk and changed in two days. The moth appears early in May and in August. It is a rare species in this locality. Larva eats Rubus and Betula.

Calocampa nupera Lint. Large and stout. Brilliant applegreen, lighter between the segments. A double lateral narrow stripe, black above and greenish white beneath. This stripe passes through the breathing orifices, which are orange colored and catch the eye at once. An inconspicuous whitish dot just above the breathing orifices, and above this three white dots (the middle one just above the other two) from which project several minute hairs. Head and legs green. Feet red. Length $60 \mathrm{~mm}$. In its early stages it is light green, closely resembling the young larva of $C$. curvimacula, and having the appearance and habits of a Geometrid, its full number of legs being developed during its successive moults. I reared a small brood of these larvæ this spring from the egg, but had no leisure to observe their successive changes. When mature they presented many striking variations, some being almost black, with the three white spots above the breathing holes strongly contrasting; others were of a rich shining brown, some pale brownish green; but the majority were of the form described above. The larva enters the ground towards the end of June, and changes to a pupa about the middle of August. The moth appears in September and October.

Calocampa curvimacula Morr. Color dirty greenish brown, appearing in certain lights as if frosted; immaculate beneath; mottled with darker shades of brown above. A narrow dorsal dirty white line edged with brown. Faint oblique blotches on the sides, composed of mottling a little darker than the ground color of the larva. Head shining brown with darker mottling. 
The whole larva is sparsely covered with short fine hairs. Length $45 \mathrm{~mm}$. A very ordinary looking larva, and forming a striking contrast to the brilliant larvæ of $C$. nupera and the two European species. When at rest it bends its head to one side, after the manner of the larvæ of Lithophane, thus differing from C. nupera, which rests straight along the stalk of its food plant. I obtained the eggs from which I reared this larva by confining a female in a box with leaves of Iris, on which it laid a large bunch. The larvæ however did not thrive on this plant, and only one or two came to maturity.

Calpe canadensis Beth. Color greenish white. A row of irregular black spots above; another row of black spots on each side, three on each segment and one between. The middle spot on each segment is larger than the other two, and partially encloses a bright yellow patch above it. Beneath dull green, contrasting with the yellowish white color of the sides. Head greenish yellow with six black spots, two larger above and four smaller about the jaws. Eleventh segment slightly humped and with three conspicuous black spots. Length $35 \mathrm{~mm}$. Spun a frail cocoon among some moss, and emerged about a fortnight after, June 22. Feeds on Thalictrum cornuti. The young larva spins a case for itself, when about to change its skin. The mature larva is very showy and conspicuous.

Roland Thaxter.

\section{Oviposition in Spiders.}

In Psyche, v. 2, p. 33-34, I described the method by which the eggs are laid and enclosed by several spiders that make cocoons attached by one side. In July last I had the good fortune to see the method of oviposition of Drassus, which carries the cocoon in its claws or leaves it loose in the nest. A female, who had been kept several days in a bottle, be-

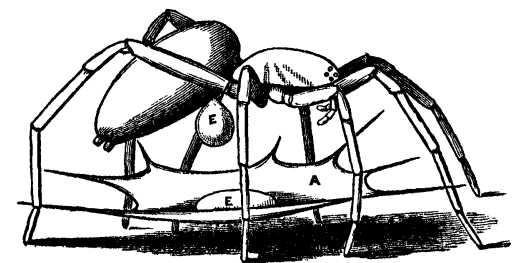

Fig. 5 . gan her cocoon early one morning, and when I first saw 

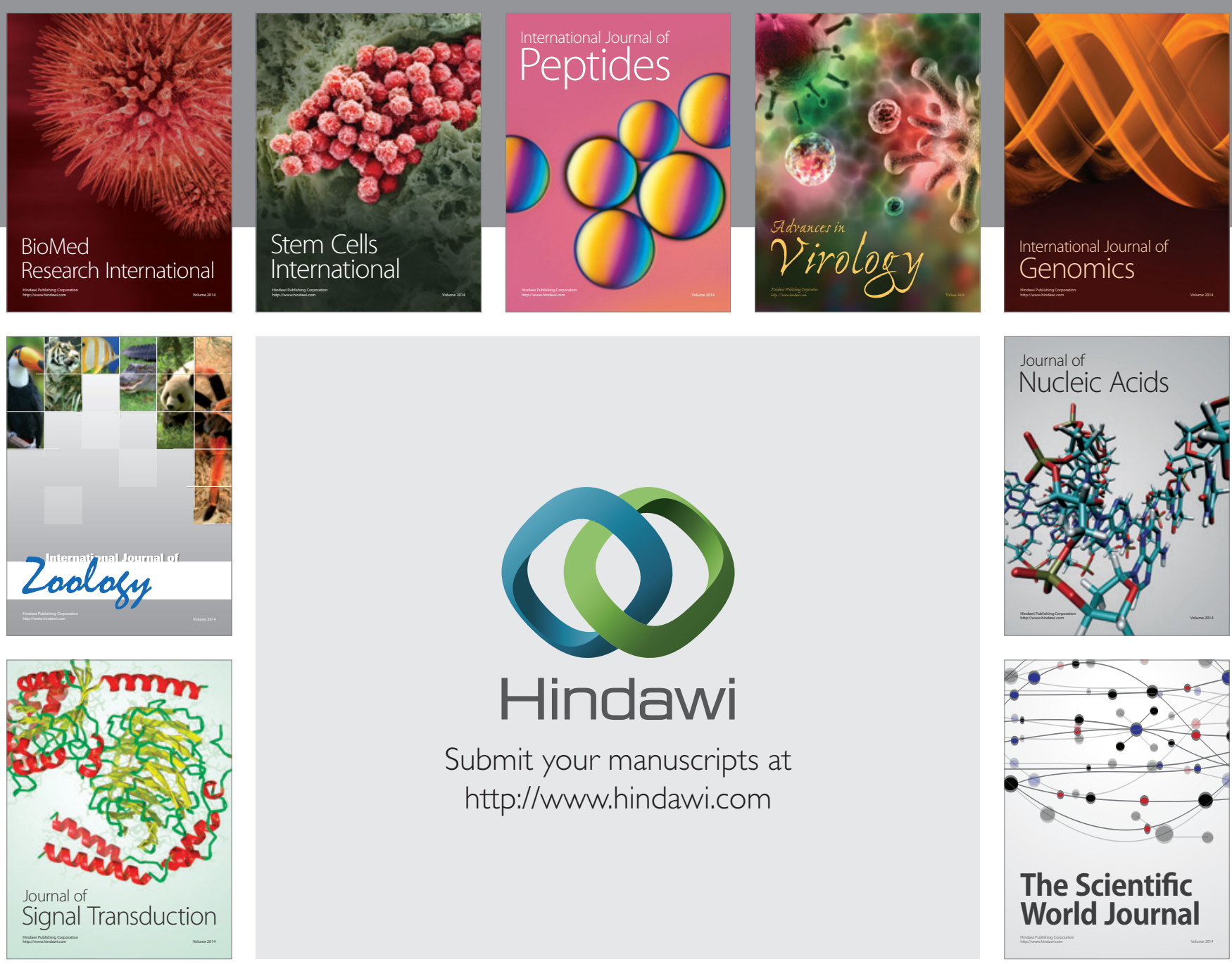

Submit your manuscripts at

http://www.hindawi.com
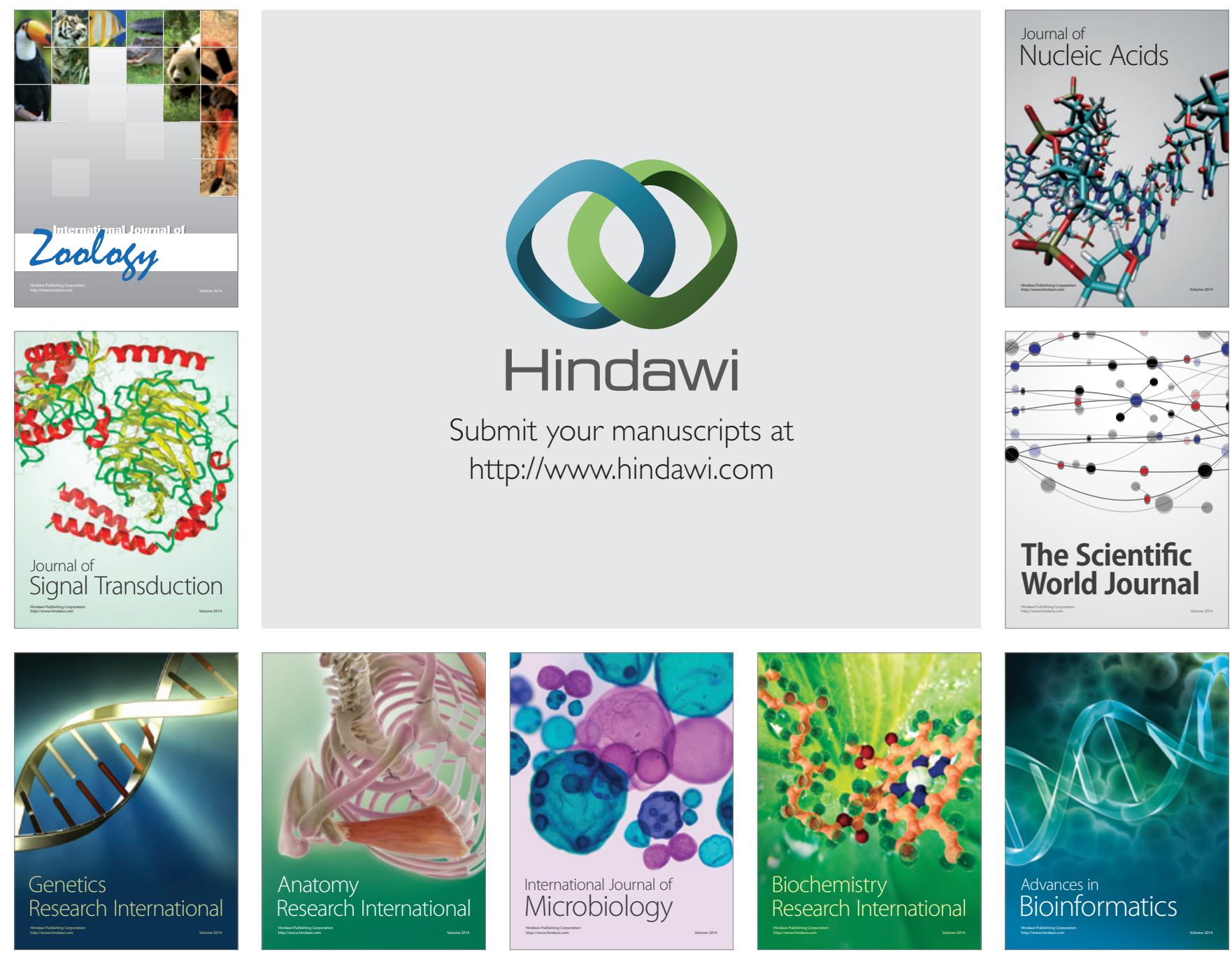

The Scientific World Journal
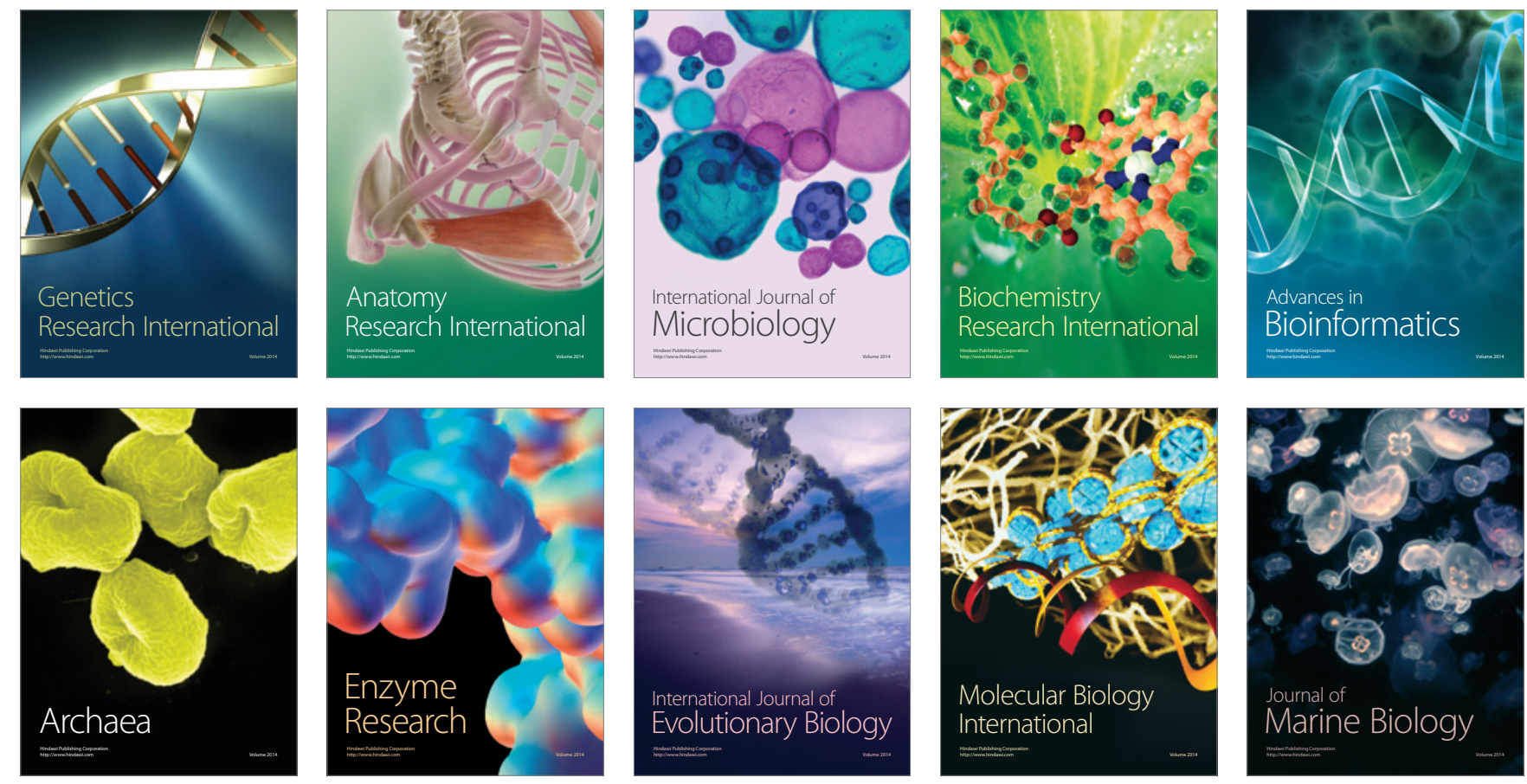